\title{
The industrial unionism movement in Greece during the first years of the political change after the fall of the Junta (1974-1981)
}

Le mouvement syndical ouvrier, en Grèce pendant les premières années après la chute de la Junte (1974-1981)

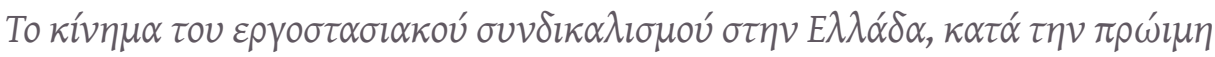



\section{Akis Palaiologos}

\section{OpenEdition}

\section{Journals}

Electronic version

URL: https://journals.openedition.org/ceb/11318

DOI: 10.4000/ceb.11318

ISSN: 2261-4184

\section{Publisher}

INALCO

Printed version

ISBN: 978-2-85831-294-8

ISSN: 0290-7402

\section{Electronic reference}

Akis Palaiologos, "The industrial unionism movement in Greece during the first years of the political change after the fall of the Junta (1974-1981)", Cahiers balkaniques [Online], 45 | 2018, Online since 05 December 2018, connection on 07 July 2021. URL: http://journals.openedition.org/ceb/11318 ; DOI: https://doi.org/10.4000/ceb.11318

This text was automatically generated on 7 July 2021.



Cahiers balkaniques est mis à disposition selon les termes de la Licence Creative Commons Attribution - Pas d'Utilisation Commerciale 4.0 International. 


\section{The industrial unionism movement in Greece during the first years of the political change after the fall of the Junta (1974-1981)}

Le mouvement syndical ouvrier, en Grèce pendant les premières années après la chute de la Junte (1974-1981)





Akis Palaiologos

1 On July $24^{\text {th }} 1974$, the transition to democracy took place following the collapse of the


Policy Change), denotes the restoration of democracy. The fall of the military dictatorship happened in parallel with the weakening of the post-civil war mechanisms of the State which, from 1949, the year the Greek Civil war ended, until 1974, were controlling all the social activities within the country. The autocratic governance, the ban on left-wing political parties, the military interventions in politics, the rampant action of far-right parastatal organizations, the strict policing as well as the suffocating control of trade-unions, were constituting the major pillars of the State, the winners of the Civil War had established. The legalization of all left-wing parties, the referendum which abolished monarchy in 1974, the unadulterated elections in the same year, the new constitution of 1975 , the conviction of the military junta leaders, the gradual return of the political exiles, the extrication of the military from politics and freedom of the press formed the basis of the Third Hellenic Republic. ${ }^{1}$

2 At the economic level, since the beginning of the 1960's, rapid industry growth took place which, during the dictatorship period (1967-1974), grew even further as the Greek industry expanded in mass production sectors, like the chemical industry, metallurgy and the manufacturing of electrical appliances. ${ }^{2}$ During this time, industrial businesses 
were operating within a climate of protectionism with a selective system of incentives, of foreign investment attraction and development laws, which resulted in a cheap money supply for businesses to cover their excess production costs and survive. ${ }^{3}$ The Metapolitefsis era, however, which almost coincided with the global oil crisis, found the Greek industry to be overcharged by loans on the one hand, and, on the other hand, without the capacity to undertake protective measures. ${ }^{4}$

3 At the social level, during the first years of Metapolitefsis, social unrest and mass mobilisations were prevailing. Those years were colored by strikes and mobilizations of industrial workers, public sector and private sector employees, farmers and students. The early Metapolitefsis era, with its political, democratic and syndicalist liberties formed a completely new political and social framework within which those movements had developed. ${ }^{5}$

4 Within this framework, in many industries and mining businesses, new forms of collective labour action emerged, more specifically, the industrial unionism movement, which was a protagonist in the assertive struggles of the Greek labour movement during the early days of Metapolitefsis (1974-1981). The term "industrial unionism" refers to the industrial sector workers' assertions, which were expressed by workers and employees in every business, who had either formed a union or a committee and who, in most cases, were taking action autonomously, beyond any action undertaken by the official sectoral union representatives. ${ }^{6}$

The industrial unionism movement seems to have been born in 1974, at the 'National Can' canning factory in Eleusina, near Athens, when its 500 employees called for a general assembly, in order to discuss the hideous working conditions and the gruelling working hours. Management fired at once one of the workers who held a leading role in the events, a move that led to a four-day strike which ended with the worker's re-hiring. ${ }^{7}$ The mobilisation at National Can was the first big scale strike after the collapse of the military dictatorship and spurred dynamic actions in other factories too.

6 The peak of the industrial unionism movement was between 1975 and 1977. During that period, dynamic strikes and mobilisations took place mainly in electrical appliance manufacturing plants, as well as in other industrial sectors. The industrial unionism movement did not limit itself geographically to Attica; on the contrary, it was geographically dispersed, and found expression in cities like Thessaloniki and Patras but also in smaller provincial towns and in mining businesses of Northern and Central Greece. At a later stage, between 1977 and 1979, the industrial action and the strikes were in decline and became almost extinct during 1979-1981, with only very few sporadically taking place. ${ }^{8}$

7 The strikes of the movement were of substantial length. Indicatively, we may refer to the 40-day strike at Pitsos electrical appliance industry (Athens, December 1975-January 1976), the 45-day strike at the ITT communications equipment industry (Athens, 1975), the 80-day strike at the MEL paper industry (Thessaloniki, 1975), the 93-day strike at the Ladopoulos paper industry (Patras, 1975), the 110-day strike at the LARKO mining and metallurgy (Larymna, Central Greece, 1977) and the 2-month strike at the Mantoudi mine (May-April 1976) in Central Greece. ${ }^{9}$

8 However, strike action as a means of assertion was not automatically the first or the only option in the hands of employees. Other forms of mobilisation, tailored to the organisational form of the factory, like the systematic deceleration of production or 
sudden work stoppages, were taking place very frequently. ${ }^{10}$ Meanwhile, more aggressive forms of mobilisation made their appearance, like factory squats, the most well-known being the squat of the ESKIMO electrical appliance industry in $1975 .{ }^{11}$

9 Next, the causes of the birth of the industrial unionism movement will be presented, along with its demands and its efforts to connect with society, as well as the innovative elements it offered to the Greek labour movement and its confrontation with the official syndicalism and the state will also be presented. Finally, a reference to the industrial unionism movement in Patras will be made, which constitutes the subject of my-in progress-PhD thesis.

The current announcement is based on the entirety of the available bibliography on the industrial movement. The bibliography is rather poor and contradictory, and is comprised mainly of articles, both academic and not. However, during the last few years, MA dissertations have highlighted various aspects of the movement. As far as sources are concerned, the national and Patras press is primarily used, along with data from economic censuses pertinent to the national industrial activities, as published by the Hellenic Statistical Authority.

\section{The causes}

- One major factor leading to the appearance of the industrial unionism movement were the radical changes pertinent to the social division of labour that took place during the 1960's resulting in the birth of a new industrial working class. The increase in industrial employment was substantial: during the decade 1971-1981, more than 81000 new workers were added to the industrial labour. At the same time, along with the increase in industrial employment, a concentration thereof was noted in mid- and large-scale production activities: in 1978, 54,2\% of the total of 406831 industrial workers were working in 751 units employing 100 or more individuals each. ${ }^{12}$

- A second cause was that the industrialization during the dictatorship period as well as that of the post-civil war era, was substantially supported by the low level of workers' wages, which remained constant for several years. ${ }^{13}$ In essence, the post-civil war industrialisation was based on a policy of economic exploitation of a non-negotiable, state-guaranteed, cheap labour.

- A third factor was the collapse of the post-civil war mechanisms in relation to trade-unions. The state unionism entities were incapable of operating effectively after the fall of the dictatorship and there was no access to industrial workers on their part. On the other side, already since the junta period the left-wing entities of the pre-dictatorship era had been expelled from the unionist areas. ${ }^{14}$ In this framework, almost immediately after the fall of the Junta, in many factories, with an almost total absence of collective bodies, initiatives spun, which aimed toward coordinating the unionism struggles of workers at the business level, and revolved around claiming wage increases as well as the workers' basic right of negotiating wage levels and working conditions. ${ }^{15}$

11 If we can attempt to describe the characteristics of the industrial workers who participated in the hundreds of actions organised by industrial unionism movement, these were the following:

- First, they were young, and, at a conscious level, the military dictatorship seemed completely delegalised to them. ${ }^{16}$ 
- Second, a large portion of this labour was unskilled. Many industrial businesses, with most prominent example the businesses in the electrical home appliance industry, were mainly assembly units and not units of mechanical specialisation. ${ }^{17}$ To a great extent, these workers, being unskilled, were not supporting the divisions and segregations contained in skilled labour.

- The third element has to do with the labour intensification itself in many Greek industrial units. More specifically, the unfavourable working conditions, the labour intensification, the timing of work phases, the numerous occupational accidents and the insufficient health and security standards constituted a deeply wounding experience at both personal and collective level. ${ }^{18}$

\section{The demands and the connection with society}

The above roughly outlines the framework of the interpretation of the core demands expressed via mobilisations undertaken by the industrial unionism movement: wage raises, amelioration of working conditions and re-hiring of fired union members. Apart from these actions, the factory unions made numerous interventions against the intensification of work and were often openly expressing doubts about the managerial privilege. In this direction, some more radical demands were vocalised, related to co-management forms of factory operation and administration. ${ }^{19}$

At the same time, the industrial unionism movement extended laborious efforts in order to connect with society, asking for its support. Various efforts were made in this direction: publications of tracts and special strike-related newspapers in order to sensitise the public, artistic shows held at the premises of the strike in progress, open meetings in public spaces, road seizures and protests. ${ }^{20}$

In whole, "the need to connect the struggles with society was emerging from the fermentations of a class awareness process and the formation of new collective mentalities, which produced new speech, in stark contrast with the outworn ideology of the Civil War winners. The industrial workers' struggles were taking on a wider class dimension that was expressed also through these initiatives". ${ }^{21}$

\section{The innovative elements}

The foundational contribution of the industrial workers' movement is that the establishment of the industrial unionism, contributed to the collapse of the traditional structure of the same-profession and sectoral trade unionism, which prevailed until that time in Greece. The industrial unionism brought internal, everyday functional democracy to the industrial workers' movement, when same-profession trade unionism was reproducing the technical division of labour and sectoral trade unionism was placing union action, its organisation and its control outside of the daily collective action of every factory's workers and employees. ${ }^{22}$

\section{The multilevel confrontation}

16 The appearance and the dynamism of the industrial unionism movement clashed with the institutionalised trade union structures. It should be said that the state unionism 
had a number of malaises: paternalistic unionism phenomena, disintegration of labour unions, governmental dependency of senior union institutions as well as a complex and austere legislative context. ${ }^{23}$

The afore mentioned malaises stood in stark contrast to the organisational structure of industrial unionism. Therefore, the industrial unionism movement strongly confronted the traditional state unionism entities, as this was expressed by the General Confederation of Greek Workers (ГᄃEE), which took a hostile stance towards the industrial unionism movement from the start. ${ }^{24}$

More than anything else though, the industrial movement confronted state repression The industrial movement was constituting a threat in many ways: its dynamic radicalism, grafted with wider social approval, was practically impossible to be absorbed and institutionally integrated, whereas its political imperatives were constituting, even if only embryonically, views concerning the overall questioning of capitalist production. As a result, the industrial movement was severely attacked. Institutionally, the reference point in this whole process was law no. 330/1976, which placed suffocating restrictions on any strike activity, institutionally levelled workers strike and employer lock-out, legalized strikebreaking mechanisms and banned non-declared strikes by legally established unions.

Based on this law thousands of lay-offs, trials and convictions of labour union members followed; on top of that, police violence at mobilised workplaces reached its climax. The forceful confrontation of the mobilisations led, on the one hand, to the decimation of the workers leading the labour struggles of this era, and on the other, to the industrial unionism movement's enfeeblement taking place in 1979. Overall it constituted the most essential reason for its weariness and, eventually, its dissolution.

\section{Patras and industrial unionism}

Patras is the third most populated city in Greece and its industrial activity begins during the second half of the $19^{\text {th }}$ century. ${ }^{25}$ During the period under examination, the city had a population of 130,000 citizens and a substantial labouring class comprised of 16,000-18,000 industrial workers, employed in more than 2000 industrial and craft-related businesses. ${ }^{26}$ The industrial sectors employing the largest portion of the workforce were the textile, ready-to-wear clothing, cement, chemical and paper manufacturing sectors. As far as the division of labour is concerned, a large portion of the city's workforce was employed in units comprising over 30 workers. More specifically, the national industrial census carried out by the Hellenic Statistical Authority in 1978, notes the existence of 68 plants with more of thirty employees each and a total of 9.097 employees. ${ }^{27}$ All in all, during the 1971-1981 decade, Patras was the provincial town with the greatest industrial activity, following the Attica basin and Thessaloniki. ${ }^{28}$

21 Based on the available sources, between 1974 and 1981, 10 cases of industrial union establishment are noted, as well as the establishment of numerous factory committees. The majority of industrial unions and committees were established in the ready-to-wear clothing sector, and also in other industrial sectors, like those of cement, leather tanning and beverage bottling. It should be mentioned that the establishment of industrial unions and committees was informal; the industrial unions would be 
legally recognized, in 1982 , with the law no. $1264 .{ }^{29}$ It should also be noted that the industrial activity of Patras did not include sectors like electrical appliance manufacturing or mining and metal processing, in which, as we have seen, the industrial unionism movement was massively developed. The ready-to-wear industry developed this unionism activity since the majority of its workers were unskilled. On top of that, the factory unions and committee's establishment efforts were met with mass lay-offs, especially in the clothing industry during 1976-1977..$^{30}$ At the level of practices and organisation though, mobilisations which were fully in line with the industrial unionism methodology took place. One such characteristic case will be presented.

The strike that took place at the Ladopoulos paper industry commenced on September $17^{\text {th }} 1975$, with whole of its 800 workers fully participating in the action, having as core demand the payment of accrued salaries. The strike ended 93 days later, on December $18^{\text {th }}$, with majority of workers' demands fulfilled. ${ }^{31}$

This particular strike had characteristics that bear great resemblance to the practices of the industrial unionism movement.

First, Ladopoulos' workers made serious efforts towards the connection of their struggle with the local community. During the industrial action, the workers would carry out protest marches into the centre of the city, they would appeal to entities and unions for material and political support, they would use the local press as a means to communicate their demands and they would hold open meetings. ${ }^{32}$ The highlight of these efforts was the all-workers rally for support, organised by the strikers as well as numerous other entities and took place in the centre of Patras on October $16^{\text {th }}$; the protesters were estimated to be around $10,000 .^{33}$

The second qualitative characteristic was the organisational structures chosen by the strikers in order to assert their claims. The major organisational mobilisation activities were undertaken by the strike committee which was established from the first day of the strike. The committee consisted of representatives of every specialisation, from paper manufacturing workers to factory accountants. ${ }^{34}$ This organisational structure unified the majority of the staff since it gave every factory worker a chance to participate in decision-making, regardless of their professional specialisation. ${ }^{35}$

\section{Conclusion}

The industrial unionism movement by "leveraging" the circumstantial potential of the Metapolitefsi era, expressed the activity of the new industrial working class in Greece. It was a movement organically tied to society and this is precisely the reason why it was successful in bringing change to employment relations in Greek industry through strike activity. ${ }^{36}$

The wage adjustments reflect, at a primary level, these changes. During 1975-1978 the annual wage increases for an industrial worker amounted to $23 \%$ in nominal terms and $8.6 \%$ in real terms, while during 1979-1980 the aforementioned indicators' values were $23.4 \%$ and $5.5 \%$ respectively. ${ }^{37}$ An even more substantial change though, was that the movement managed to impose wage adjustment while uncoupling wage determination from low productivity levels. ${ }^{38}$ 


\section{BIBLIOGRAPHY}

\section{Monographies, periodic papers}

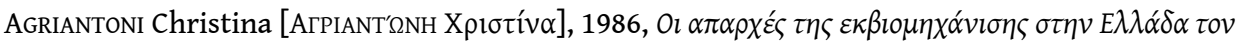





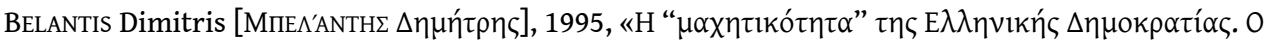

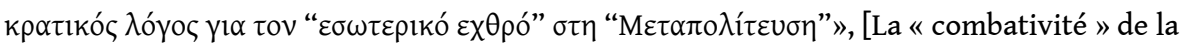

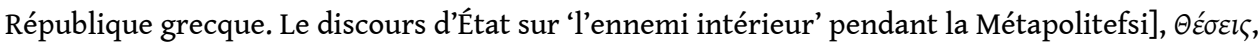
vol. 53, URL : http://www.theseis.com/index.php?

option=com_content\&task=view\&id=517\&Itemid=29, consulté le 29/11/2018.

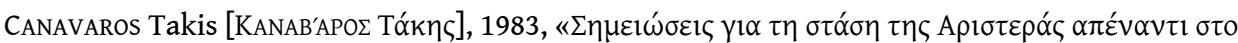

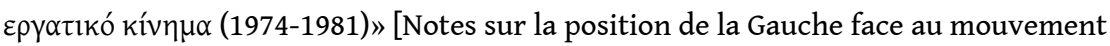
ouvrier 1974-1981], $\Theta \dot{\varepsilon} \sigma \varepsilon l \zeta$, vol 2, URL : http://www.theseis.com/index.php? option=com_content\&task=view\&id=36\&Itemid=29, consulté le 29/11/2018.

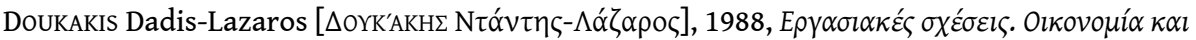

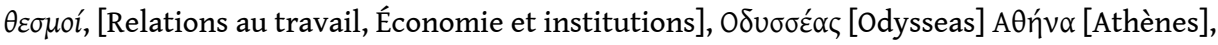
$224 \mathrm{p}$.

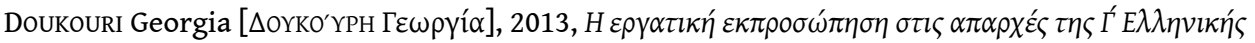

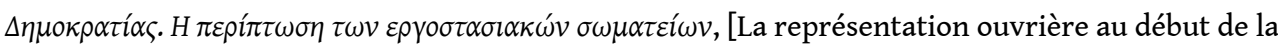
$3^{\text {ème }}$ République grecque, le cas des corporations ouvrières], MA non publié, université Pandeion, département de sciences politiques et d'histoire, Athènes.

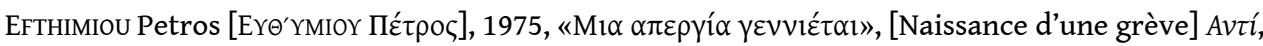
vol. 12, p. 33-37.

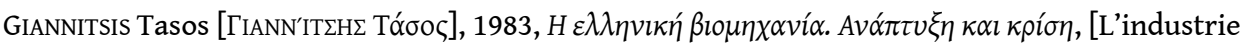

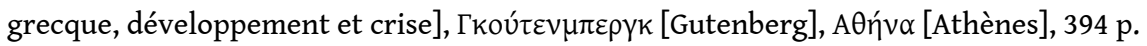




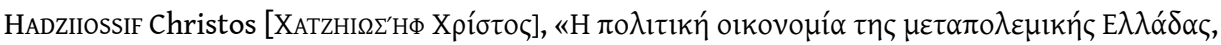
1944-1996» [L'économie politique de la Grèce d'après-guerre, 1944-1996], in KREMMYDAs Vassilis

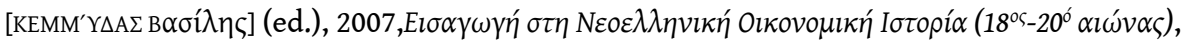

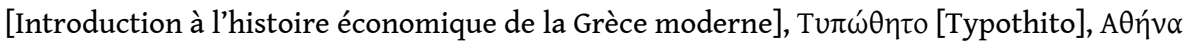
[Athènes], $320 \mathrm{p}$.

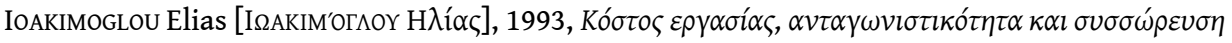
$\kappa \varepsilon \varphi \alpha \lambda \alpha i ́ o v \sigma \tau \eta v E \lambda \lambda \alpha ́ \delta \alpha$, [Coût du travail, compétitivité et accumulation du capital en Grèce], INE/ GSEE, AӨńv $\alpha$ [Athènes], $71 \mathrm{p}$.

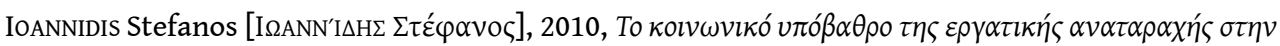

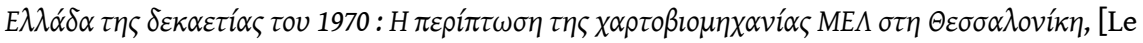
fondement social de l'agitation ouvrière en Grèce dans la décennie 1970], MA non publié, Thessalonique, université Aristote, département de sciences politiques.

IOANNIDIS Stefanos [ISANN'I $\left.\mathrm{H} \Sigma \Sigma \tau \tau^{\prime} \varphi \alpha v o \zeta\right], 2008$, The Industrial Committees' Movement in Athens, 197-79, MA non publié, université du Sussex.

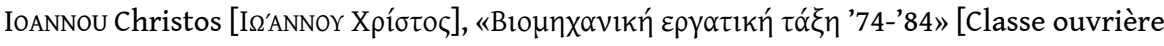



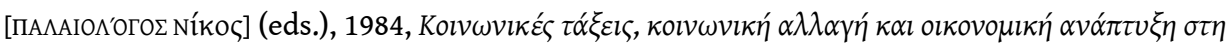

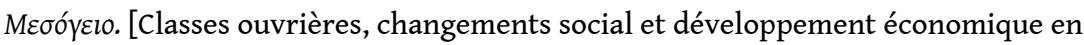

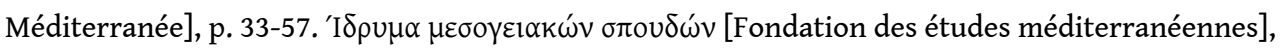
AӨńv $\alpha$ [Athènes], $319 \mathrm{p}$.

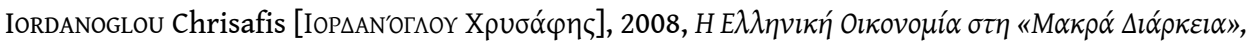

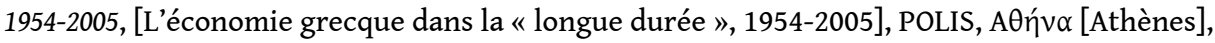
$540 \mathrm{p}$.

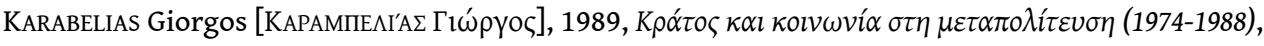

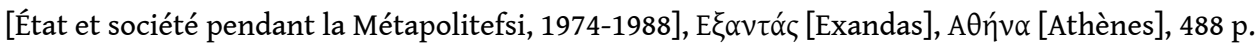

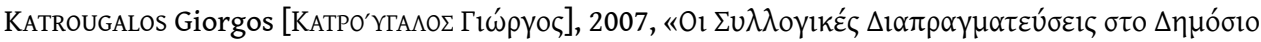

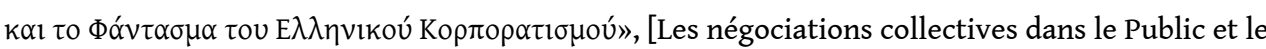


$\sigma \tau \eta v E \lambda \lambda \alpha ́ \delta \alpha$ (1974-2004), [Travail et Politique. Syndicalisme et Organisation des Intérêts en Grèce, 1974-2004], Proceedings of 10 Conference, Panteion University (18-21/5/2005), Sakis Karagiorgas Foundation, Athens 20, p. 196-212.

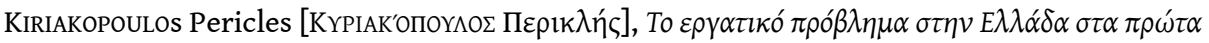

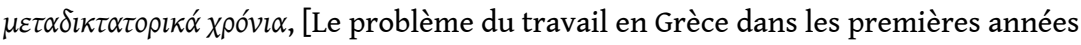

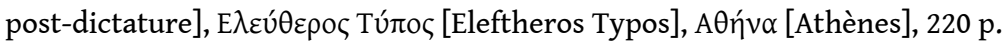

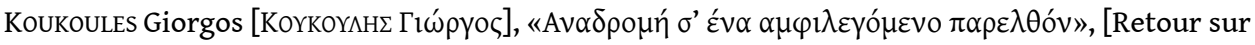

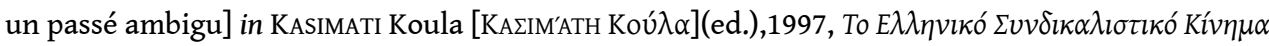

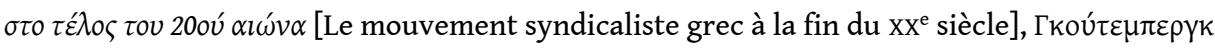
[Gutenberg], AӨńva [Athènes], 262 p.

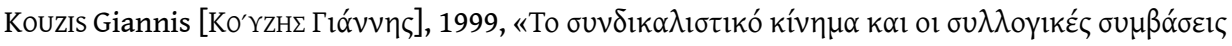

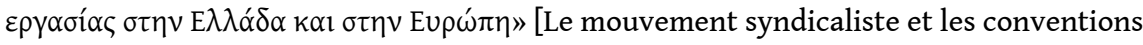
collectives de travail en Grèce et en Europe], in Theodoros SAKELLARopoulos

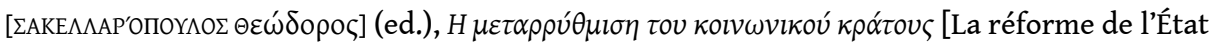

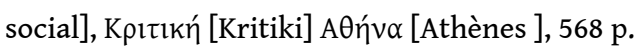




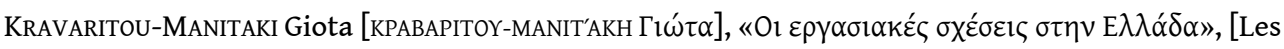

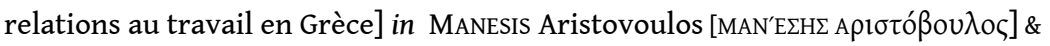

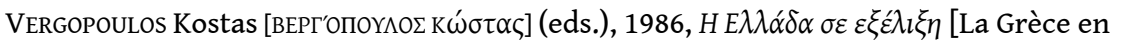

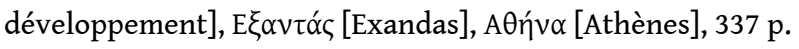

LEONTIDOU Lila, 1990, The Mediterranean city in transition. Social change and urban development, Cambridge University Press, Cambridge, 316 p.

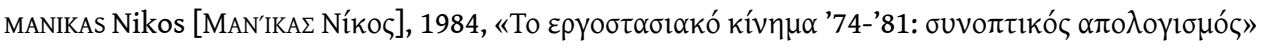

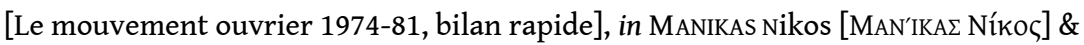

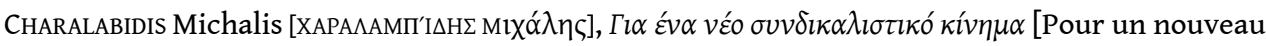

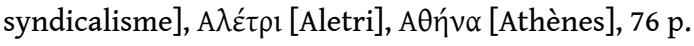

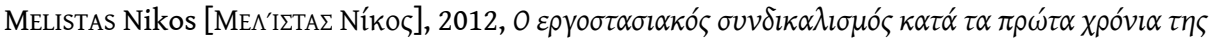

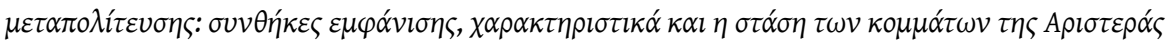

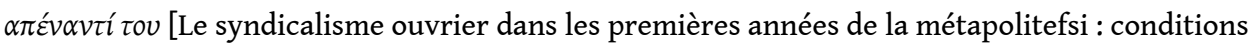
de son apparition, caractéristiques et position des partis de gauche envers lui], projet de MA non publié, Réthymnon, université de Crète.

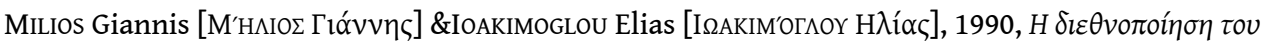

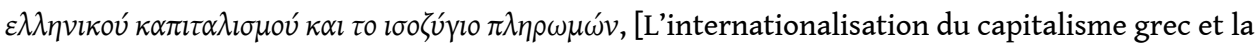

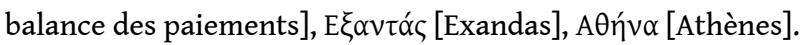

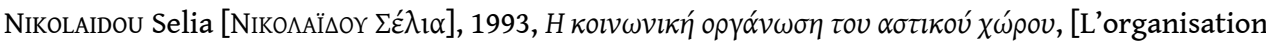

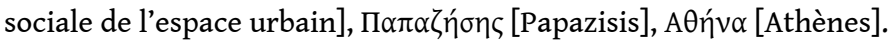

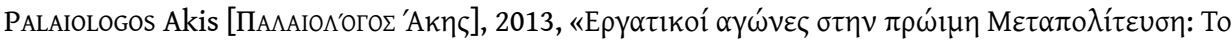

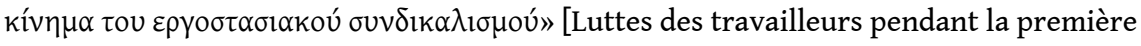

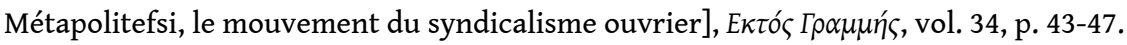

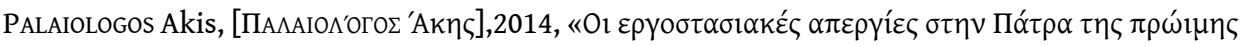

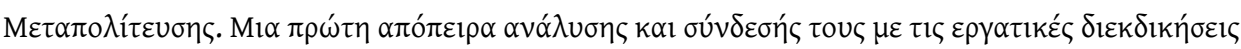
$\tau \eta \varsigma ~ \pi \varepsilon p 1 o ́ \delta o u »$, [Les grèves ouvrières à Patras dans les débuts de la Métapolitefsi, une première tentative d'analyse], communication à la $19^{9}$ ème rencontre d'été entre étudiants de MA et de thèse en Histoire moderne et contemporaine, Université de Crète, Réthymnon, 1-15/6/2014, p. 1-9.

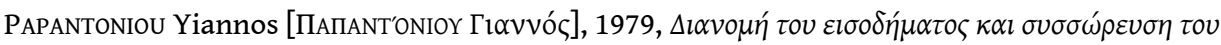

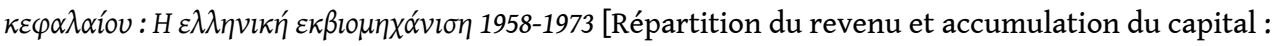

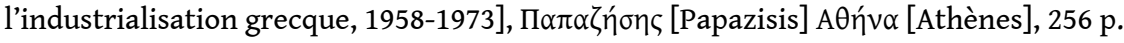

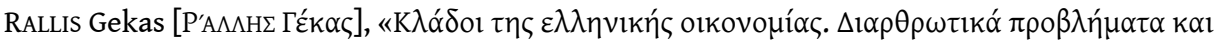

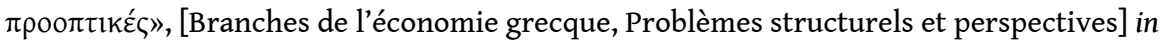

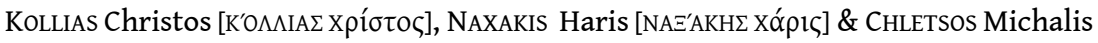

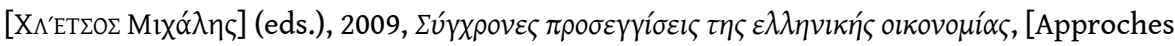

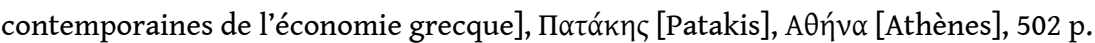

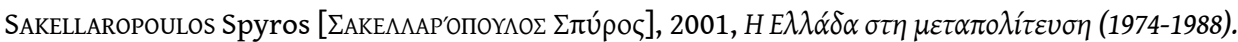

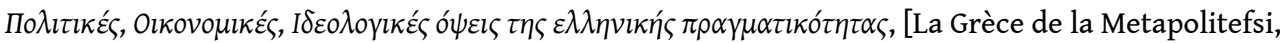

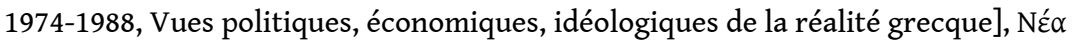

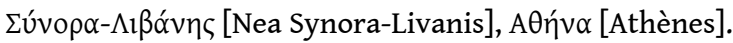

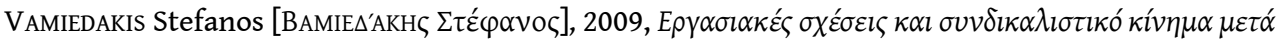

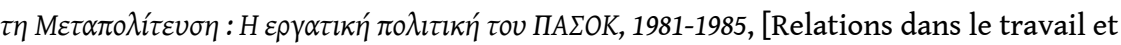


mouvement syndical après la Métapolitefsi : la politique ouvrière du PASOK, 1981-1985], MA non publié, université de Crète, Réthymnon.

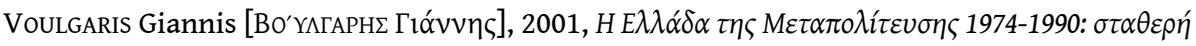

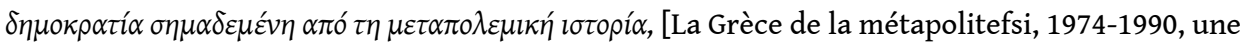

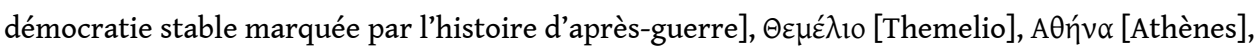
$408 \mathrm{p}$.

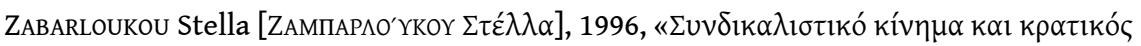

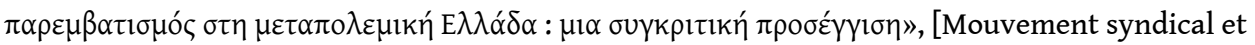
intervention de l'État dans la Grèce de l'après-guerre : une approche comparative] in

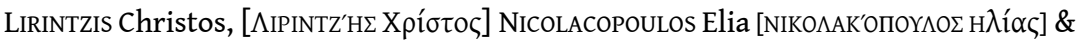

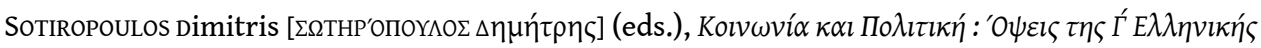
$\Delta \eta \mu о к \rho \tau \tau i ́ \alpha \varsigma$ 1974-1994, [Société et Politique ; Vues de la III République Grecque, 1974-1994],

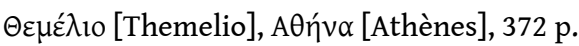

\section{Censuses}

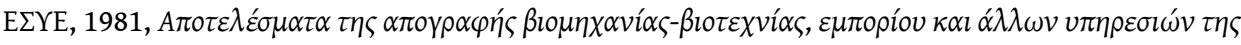
$30 \Sigma \varepsilon \pi \tau \varepsilon \mu \beta p i ́ o v ~ 1978$, [Résultats du recensement industrie-artisanat-commerce et autres services

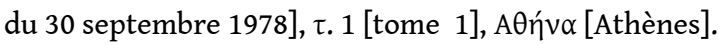

\section{Press}

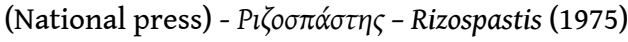

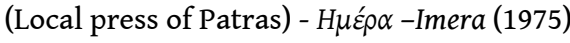

\section{NOTES}

1. Voulgaris, 2001, p. 25-32; IOANNIDIS, 2010, p. 26-27.

2. GIANNITSIS, 1983, p. 117-135.

3. HADZIIOSSIF, 2000, p. 310-313; Milios \& IOAKIMOGLOU, 1990, p. 95.

4. IOAKIMOGLOU, 1993, p. 44-49; RALLIS, 2005, p. 155-160.

5. VOULGARIS, 2001.

6. DOUKOURI, 2013, p. 47.

7. EFTHIMIOU, 1975, p. 33-37.

8. KiRIAKOPOULOS, p. 23-67; SAKELLAROPOULOS, 2001, p. 514.

9. Palaiologos, 2013, p. 45-46.

10. MANIKAS, 1984, p. 16-17.

11. Melistas, 2012, p. 15.

12. In 1960 , out of the total of 255000 industrial employees, $48,1 \%$ was employed in 436 units, each employing 100 people or more. IOANNOU, 1984, p. 36. 
13. Characteristically, the share of wages in industry value added fell from $44 \%$ in 1958 to $31,6 \%$ in 1973 , while the daily wage fell from $32,8 \%$ to $19,7 \%$. PApantoniou, 1979 , p. $135-139$.

14. IOANNOU, 1984, p. 38-39.

15. KRAVARITOU-MANITAKI, 1986, p. 289.

16. IOANNIDIS, 2008, p. 10.

17. DOUKOURI, 2013, p. 43.

18. IOANNIDIS, 2008, p. 45.

19. MANIKAS, 1984, p. 13.

20. Canavaros, 1983.

21. Melistas, 2012, p. 16.

22. IOANNOU, 1984, p. 35.

23. K oukoules, 1997, p. 58-65; Kouzis, 1999, p. 258-259; SAKellaropoulos (ed.), 1999, p. 61-62.

24. BELANTIS, 1995; IOANNOU, 1984, p. 40.

25. AGRIANTONI, 1986, p. 77-82, 114, 118, 124, 126, 232-234.

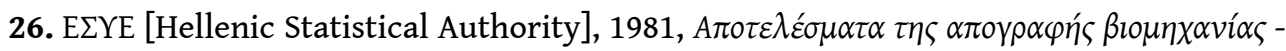

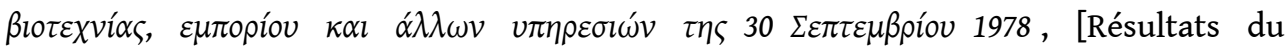
recensement industrie-artisanat, commerce et des autres services du 30 septembre 1978] Aөńva, vol.1, table 2, p. 90. For the second half of 1970's, nationwide newspapers, as well as Patras local press reckon the number of city's industrial labor in 18,000 .

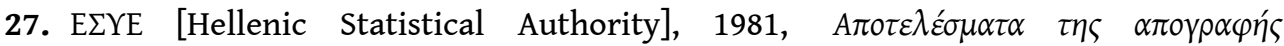

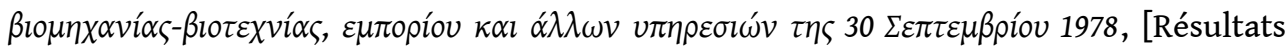
$\mathrm{du}$ recensement industrie-artisanat, commerce et des autres services du 30 septembre 1978], table 4, p. 328.

28. LEONTIDOU, 1990, p. 123.

29. VAMIEDAKIS, 2009, p. 91-109.

30. Palaiologos, 2014, p. $4,7$.

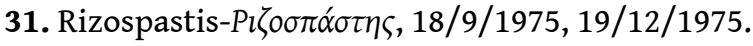

32. Imera- $H \mu \varepsilon ́ p \alpha, 29 / 9 / 1975,1 / 10 / 1975,2 / 10 / 1975,5 / 10 / 1975,8 / 10 / 1975,14 / 10 / 1975$;

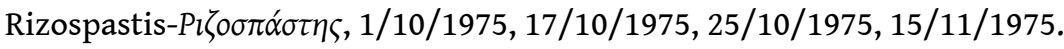

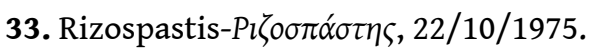

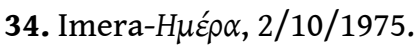

35. PAlaiologos, 2014, p. 6.

36. IOANNOU, 1984, p. 41.

37. IORDANOGLOU, 2008, p. 138.

38. DOUKAKIS, 1988, p. 50. 


\section{ABSTRACTS}

The announcement focuses on the industrial unionism movement in Greece, which was developed during the second half of the 70's. Firstly, the main political, economical and social transformations, following the collapse of the military dictatorship (1974), are presented, along with the culmination and decline phases of the industrial unionism movement. Next, the causes of the birth of the industrial unionism movement are presented, along with its demands and its efforts to connect with society. The innovative elements it offered to the Greek workers' movement as well as its confrontation with the official syndicalism and the state are also presented. Finally, a reference to the industrial unionism movement in the city of Patras is made.

Cette communication traite du syndicalisme ouvrier qui s'est développé en Grèce dans la seconde moitié des années 1970. On présente d'abord les principales transformations politiques, économiques et sociales qui ont eu lieu après l'effondrement de la dictature militaire en 1974, de même que les différentes phases de développement et de déclin de ce syndicalisme ouvrier. Ensuite, on développe les raisons de la naissance de ce mouvement, ses demandes et ses efforts pour rester en lien avec la société. On présente également les éléments novateurs qu'il a offert au mouvement des travailleurs grecs, de même que son affrontement avec le syndicalisme officiel et l'État. Enfin on fera référence au mouvement syndical ouvrier dans la ville de Patras.

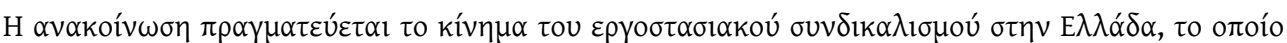

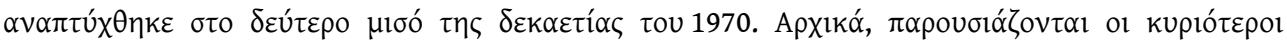

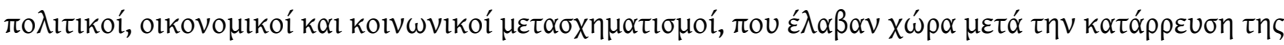

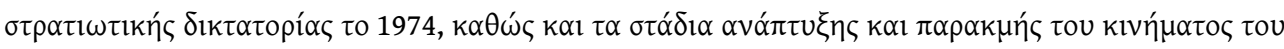

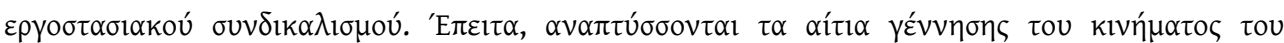

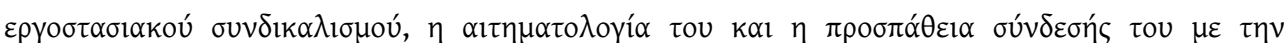

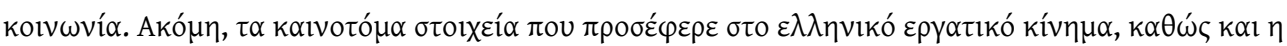

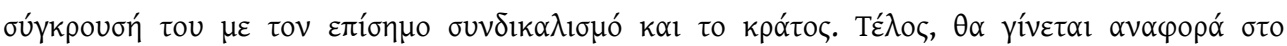

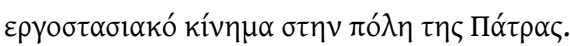

\section{INDEX}

Mots-clés: mouvement syndical ouvrier, mouvement syndical ouvrier, Patras, Patras, grèves, grèves, Grèce, Grèce, histoire sociale, histoire sociale, histoire contemporaine, histoire contemporaine

Keywords: industrial unionism movement, strikes, Patras, Greece, contemporary period, social history, trade- unions

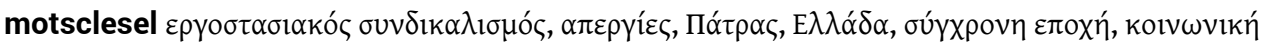

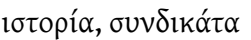

motsclestr işçi sendikası hareketi, grevler, Patras, Yunanistan, çağdaş dönem, sosyal tarih, sendikalar

\section{AUTHOR}

\section{AKIS PALAIOLOGOS}

Histoire moderne et contemporaine, université de Ioannina 